\title{
RFLP Report
}

\section{ALLELE FREQUENCY OF HinfI RESTRICTION FRAGMENT LENGTH POLYMORPHISM (RFLP) AND DINUCLEOTIDE REPEAT POLYMORPHISM IN THE WILMS TUMOR GENE (WTl) AMONG THE JAPANESE}

\author{
Tadashi Matsumoto, Miho Okumura, Tomoko Sawai, \\ Shigeru AokI, and Yoshiro Tsum \\ Department of Pediatrics, Nagasaki University School of Medicine, \\ Sakamoto 1-7-1, Nagasaki 852, Japan
}

The frequency of HinfI RFLP and dinucleotide (CA) repeat polymorphism for the WT1 located to chromosome $11 \mathrm{p} 13$ among the Japanese were estimated. Each polymorphism showed high frequency of heterozygosity and segregated independently.

Key Words polymorphisms, WT1 gene

DNA from 50 Japanese individuals (25 males and 25 females) was amplified by polymerase chain reaction (PCR) followed by HinfI and/or DraI digestion and electrophoresis.

Primers for PCR. A primer set designed by Hoban and Kelsey (1991) as WT11: 5'-GCCTGGAAGAGTTGGTCTCT-3', and WT12: 5'-ACACAGTAATTTCAAGCAACGG-3'.

Condition of PCR. $100 \mathrm{ng}$ of genomic DNA was amplified with 50 pmol of each primer in $50 \mu \mathrm{l}$ PCR reaction mixture $(10 \mathrm{mM}$ Tris-Cl, $\mathrm{pH} 8.4 / 1.5 \mathrm{mM} \mathrm{Mg}-$ $\mathrm{Cl}_{2} / 50 \mathrm{mM} \mathrm{KCl} / 250 \mu \mathrm{M}$ of each dNTPs/3 units of Taq polymerase). Denaturation at $94^{\circ} \mathrm{C}$ for $1 \mathrm{~min}$, annealing at $60^{\circ} \mathrm{C}$ for $1 \mathrm{~min}$, and extention at $72^{\circ} \mathrm{C}$ for 2 min for 30 cycles. PCR products were electrophoresed on $6 \%$ polyacrylamide gel (PAG) in $1 \times$ TBE buffer, then stained with ethidium bromide.

\section{1) HinfI RFLP}

Polymorphic and constant DNA fragments. A two-allele polymorphism with $240 \mathrm{bp}$ (allele a) and $131 \mathrm{bp}+109 \mathrm{bp}$ (allele b), and three constant fragments (380 bp, 293 bp, and 41 bp) as described by Hoban and Kelsey (1991).

Allele frequency. 0.39 for allele " $a$ " and 0.61 for allele " $b$ ". $P I C=0.36$. The frequency of expected and observed heterozygosity was 0.48 and 0.44 , respectively.

2) CA repeat polymorphism detected after DraI digestion (Fig. 1)

Polymorphic and constant DNA fragments. A three-allele polymorphism with

Received November 11, 1993; Revised iersion accepted December 27, 1993. 


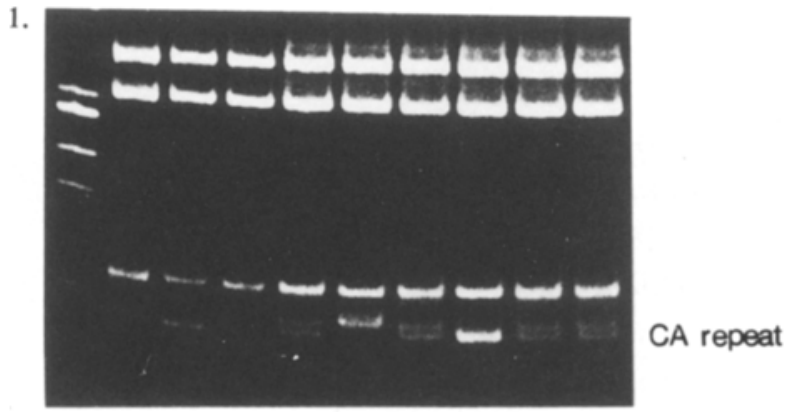

WTVDral
2.

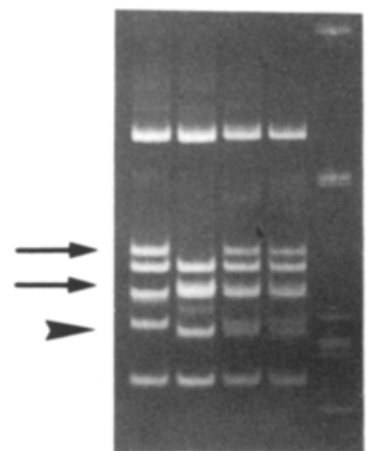

Fig. 1. CA repeats polymorphism following DraI digestion. Left side lare shows rhamda phiX 174/HaeIII size marker.

Fig. 2. HinfI RFLP and CA repeats polymorphism following HinfI and DraI digestion. Arrows and arrow head indicate HinfI RFLP and CA repeats polymorphism, respectively. Right side lane shows size marker as in Fig. 1. 40 bp and 33 bp bands are not seen in this figure.

$106 \mathrm{bp}$ (allele a), $104 \mathrm{bp}$ (allele b), and $102 \mathrm{bp}$ (allele c) and three constant fragments (409 bp, $315 \mathrm{bp}$, and $127 \mathrm{bp}$ ). These product length were determined in $6 \% \mathrm{PAG} / 8 \mathrm{M}$ urea gel electrophoresis.

Allele frequency. 0.55 for allele " $a$ ", 0.35 for allele " $b$ ", and 0.10 for allele "c". $\mathrm{PIC}=0.45$. The frequency of expected and observed heterozygosity was 0.56 and 0.31 , respectively.

3) Double digestion with HinfI and DraI

The PCR products were digested with HinfI and DraI simultaneously (Fig. 2). The $109 \mathrm{bp}$ HinfI polymorphic band is cut to polymorphic $33 \mathrm{bp}+$ constant 77 bp bands, and HinfI $380 \mathrm{bp}$ band is cut to constant $153 \mathrm{bp}, 127 \mathrm{bp}$ and polymorphic CA repeats bands by DraI.

Polymorphic and constant fragments: $164 \mathrm{bp}$ (allele "a") and $131 \mathrm{bp}+33 \mathrm{bp}$ (allele "b") HinfI polymorphism and CA repeats polymorphism. Constant fragments were $293 \mathrm{bp}, 153 \mathrm{bp}, 127 \mathrm{bp}, 76 \mathrm{bp}$, and $40 \mathrm{bp}$.

Comments. This WTI PCR product can be used to search two kinds of polymorphisms by two kinds of endonuclease digestion simultaneously and these two kinds of polymorphism segregate in Mendelian inheritance. As DraI cut just 5 ' prime of CA repeats and polymorphic fragments length are rather short, this polymorphism is easily detectable on polyacrylamide gel electrophoresis. The allele frequency of HinfI RFLP in the Japanese was inverse of that in the Caucasian (Hoban and Kelsey, 1991) indicating the difference of the species. Since these polymorphisms are located within exon 10 of $W T l$ and these two kinds of polymorphisms segregate independently, they are useful for the study on loss of heterozygosity ( $\mathrm{LOH}$ ) or genomic imprinting of the gene.

Reference. Hoban PR, Kelsey AM (1991) Nucleic Acjds Res 19: 1164 